\title{
8. Citizen-centred policy making under Rudd: network governance in the shadow of hierarchy?
}

\author{
DAVID MARSH, CHRIS LEWIS AND PAUL FAWCETT
}

The 2007 Policy Platform of the Australian Labor Party (ALP) asserted that 'Labor will pursue new and innovative measures designed to foster greater participation and engagement of the Australian population in the political process' (cited in Manwaring 2010). It seemed that Labor was following a trend that many authors have identified as a move from government to governancemore specifically to 'network governance', ${ }^{1}$ in which governments encourage greater participation, especially by 'expert citizens' (see Bang 2005), in policy making, recognising that they can at best steer, not row (see Osborne and Gaebler 1992). Indeed, as Martinetto (2003:593) contends, this idea has taken on a 'semblance of orthodoxy'. In this chapter, we examine two major initiatives taken by the Rudd government that were designed to deliver on this platform promise: the 2020 Summit and the Community Cabinets initiative. Our aim is to assess both the extent to which these initiatives marked a genuine move towards greater participation and, more broadly, whether they reflect a move towards network governance. We begin, however, with a brief discussion of the literature on governance that we use to frame this chapter.

\section{Models of governance}

Rhodes (1997), among many others, distinguishes between three modes of governance-hierarchy, markets and networks - arguing that networks have become the dominant mode. ${ }^{2}$ Newman (2005:11) outlines this view:

\footnotetext{
1 The network governance literature is only loosely related to the literature on policy networks (see Marsh and Rhodes 1992), and owes much more to the European literature on modes of governance (see, for example, Kickert et al. 1997). For a more detailed discussion of these issues, which pays particular attention to Rhodes' works, see Marsh (forthcoming).

2 Actually, Rhodes' view has changed to a significant extent over time as he has embraced interpretativism and a 'decentred' approach to polity. He still, however, sees the network governance 'narrative', and the related differentiated polity narrative, as superior to the more hierarchical perspective of the Westminster
} 
It is argued that the capacity of governments to control events within the nation state has been influenced by the flow of power away from traditional government institutions, upwards to transnational bodies and downwards to regions and sub-regions. The old mechanisms of 'control through hierarchy', it is suggested, have been superseded by the rise of markets during the 1980s and early 1990s, and by the increasing importance of networks and partnerships from the mid-1990s onwards. ${ }^{3}$

Many do not accept the blanket claim about the rise of network governance. In particular, it is argued that the distinction between government, based on hierarchy and markets, and governance, based on networks, creates a dualism, when it is better seen as a duality. From this perspective, governments oversee the various modes of governance through a process of meta-governance: 'they get involved in redesigning markets, in constitutional change and the juridical re-regulation of organizational forms and objectives, in organizing the conditions for self-organization' (Jessop 2004:70-1).

As such, Fawcett (2009:24) contends that, while hierarchies, markets and networks are distinct modes of governing, hierarchy and control remain

an important, if not the most important, form of coordination and governance, whether it is actively imposed on others from above or used as a latent threat to ensure compliance. This is because the state is typically understood to have retained its capacity to intervene in the activities of self-regulating markets and networks.

As such, meta-governance involves attempts by the state to coordinate modes of governing. For Jessop (2004:65), these 'different forms of coordination (markets, hierarchies, networks, and solidarities) and the different forms of self-organization characteristic of governance take place in the shadow of hierarchy'. In our view, in Westminster systems particularly, one aspect of such meta-governance is the way in which the discourse of network governance and increased participation in the policymaking process is used as a means of legitimising decisions that have already been taken. It is therefore not only a discourse that serves to mask the continued role of hierarchy but also a political system that is itself underpinned by a hierarchical conception of democracy.

model (see Marsh forthcoming; Rhodes et al. 2009).

3 Within the literature on network governance there is considerable focus on the role of experts, but in our view there is a tension within the literature between those who see network governance as largely involving experts and those who see it as more broadly participatory (for a fuller discussion of this issue, see Fawcett and Marsh 2010). As we shall see, this is a tension evident in our case studies; so, for example, the 2020 Summit was promoted as a participatory initiative, but it largely involved expert citizens. 


\section{Rudd's mode of governance: towards network governance?}

Glyn Davis, co-convenor with Rudd of the 2020 Summit, argued that '[d]uring his first weeks in office, Kevin Rudd evaluated various ways to gather voices outside the usual channels' (Davis 2008:379). The idea to supplement the formal political process and incorporate experts and, to a lesser extent, ordinary citizens, into the policymaking process was therefore at the core of both the 2020 Summit and the Community Cabinet initiative.

\section{The 2020 Summit $^{4}$}

The 2020 Summit was held on 19 and 20 April 2008, six months after the Rudd government took office. It claimed that the Summit would

- harness the best ideas across the nation

- apply those ideas to the 10 core challenges that the government has identified for Australia - to secure our long-term future through to 2020

- provide a forum for free and open public debate in which there are no predetermined right or wrong answers

- produce options for consideration by government in each of the Summit's 10 areas $^{5}$

- $\quad$ stimulate a government response to these option papers by the end of 2008 with a view to shaping the nation's long-term direction.

So, the Rudd government seemed to view the Summit as an exercise in network governance, drawing together the best minds in Australia to address some of the most crucial, difficult and complex public policy problems facing the country. As Glyn Davis (2008:381) argued:

The Australia 2020 Summit can be understood as a new government addressing a demand for public participation by an articulate and vocal citizenry. The Summit offered a new way to communicate directly with people, outside the standard pattern of policy debates, political institutions and the media selection of issues.

\footnotetext{
4 The analysis here is based upon the information published by the government on the 2020 Summit, interviews with 20 participants in the Summit, including two area chairs, and a wide variety of secondary material, most of it from the press, but some of it from the academy.

5 The 10 areas were: the productivity agenda; the future of the Australian economy; sustainability and climate change; rural Australia; health; communities and families; Indigenous Australia; creative Australia; Australian governance; and Australia's future in the world.
} 
Similarly, the government's post-Summit report (see < http://www.australia2020. gov.au/about/index.cfm>) asserted: 'Government, irrespective of its political persuasion, does not have a monopoly of policy wisdom. To thrive and prosper in the future we need to draw on the range of talents, ideas and energy across the Australian community.'

Many of the Summit participants whom we talked to acknowledged that the government was stressing the need to incorporate expert citizens, and others, into a process designed to produce the best policy solutions to complex problems, outside the normal parliamentary system. As one participant in the governance stream put it:

One of the things that [was] going on [was] Rudd's attempt to use the media to re-engage people with the centre of the polity, and, by putting himself up there and inviting people in, he [was] actually attempting to use the media to make these communicative links, which would have once been done by parties.

The Summit's initial report was published quickly, while the final report was published on 31 May. Individuals were subsequently able 'to contribute their ideas and be part of this conversation about Australia's future by making a submission on line' (<http://www.australia2020.gov.au>). The government's response to the 900 'ideas' in the final report was published in April 2009.

Here, we focus on three key questions (for a more extended discussion, see Fawcett and Marsh 2010).

1. Who was involved in the Summit?

2. How were the recommendations of the Summit developed?

3. What effect has the Summit had on subsequent public policy?

\section{Who was involved in the Summit?}

Of course, considerable efforts were made to make the Summit broadly representative. As Davis (2008:382) pointed out: 'Planning for the 2020 Summit reflected [the] atomisation of society. It would be a gathering of individuals not representatives.' In demographic terms, 51 per cent of the participants were women, while the Australian Capital Territory and the Northern Territory, as well as people in the forty-five to fifty-four-year age group were over-represented, compared with the general population (Nethercote 2008).

A number of our respondents, without prompting, used the phrase 'the usual suspects'. ${ }^{6}$ Similarly, Carson (2008:1) argues that the governance stream 'was

6 Certainly, many participants were known to each other and a socio-metric analysis of the membership would be interesting. 
heavily weighted with academics (including constitutional lawyers), former and current politicians, journalists, people from think tanks and non-governmental organisations, students and a few members of the public...This then was primarily a gathering of specialists ${ }^{\prime} .^{7}$

At the same time, some participants who were not among the usual suspects felt marginalised. As one young member of the security stream put it: 'We students felt a lot of the time that, because we didn't have the experience and perhaps eloquence, and the detailed knowledge that most others had, we found it a little frustrating, we were kind of jumping up and down with our hands in the air, and not being listened to.'

Particular attention was paid to ensuring a gender balance and to including adequate Indigenous representation. That was not, however, always welcomed; indeed, it was, perhaps, not always appropriate. In this vein, another man in the security stream echoed the views of the earlier participant in arguing that

at least in my panel, which was the security and foreign affairs one, there were actually very few people with genuine expertise invited. I would classify myself as someone with some expertise, but a lot of the people invited, well, first of all, over 50 per cent of them had to be women, and it's not an area in which there are that many women professionals for a whole range of reasons.

Relatedly, Twomey (2008:15) argues that there was a tension because of the nature of the participants; they were neither one thing (experts who had knowledge) nor another (representatives of the community/general public who could have been informed).

\section{How were the recommendations of the Summit developed?}

A number of issues were raised about the process. First, many were sceptical about the celebrity aspect of the Summit. One participant in the security stream argued: 'I became quite cynical about the whole thing. The balance was very much weighted towards these sort of set-piece public events, which were pretty vacuous to be honest, very vacuous in some cases, and there was a relatively short time for discussion and negotiation' (see also Twomey 2008:17).

Certainly, there was a clear element of celebrity politics involved in the operation of the Summit, with much of the media coverage of the event concentrating on

7 In contrast, a participant in the security stream emphasised: 'I have to say I was quite surprised at...the lack of heavy hitters in there.' 
celebrities, leading some participants to speak cynically about that aspect of the process. Most dramatically, a participant in the creative Australia area, cochaired by Cate Blanchett, staged a walkout in protest against this celebritisation.

A number of participants were also concerned about the way the process of arriving at the key theme ideas was managed (see also Manne 2008a, 2008b). As Guest (2008:9) argues:

It became clear on day two that the aim was to produce a Final Statement of Outcomes that represented a consensus among the group on a given topic, rather than a statement capturing the range of ideas that were discussed. It was to be a political document, and that rendered it banal and virtually meaningless.

For many participants, this meant that much discussion was within existing parameters. A security-stream participant claimed:

One of the things I knew, having done the ACT [preliminary] one, was that truly new ideas didn't have a shot in hell, because you've got, at best case, 36 hours and you don't have enough time in 36 hours to get something from unknown to acceptance, so walking in with a truly new idea you're out of luck, don't even start it.

In addition, the fact that complex issues and discussions had to be reduced to a number of bullet points concerned participants. Here, Twomey (2008:17) recalled: 'At one stage the governance group facilitator said that what was being proposed had to be reduced to a T-shirt slogan by 4 pm. He was half joking.' A participant in the productivity theme made the point more forcefully:

There was always this sensitivity about being too prescriptive until the very end of the Summit when, of course, all the bureaucrats disappeared into the cabinet room and they crunched all the ideas into the ones that I think the government thought well, okay, these are at least palatable.

The process had a great impact on what came out in terms of the substance; it really was designed for big ideas that could be quickly captured in a PowerPoint line; this meant that some of the more innovative ideas didn't fair very well, as they weren't able to rely on established concepts or ideas.

In a similar vein, a security-theme participant emphasised:

The draft communiqué that came back on the Sunday morning after it had been through Rudd and Glyn Davis had eliminated all the suggestions we had put forward from our group and replaced them with language that wasn't ours and didn't come from the group at all. We then 
had to rework our suggestions, put them into a more politically palatable language, send them back up, along with various pointed comments that the media would be very interested to hear about the way this had been handled, if we got rolled again and they did find their way into the final communiqué. I didn't think it was necessarily a top-down process but it was certainly a very managed process - highly managed.

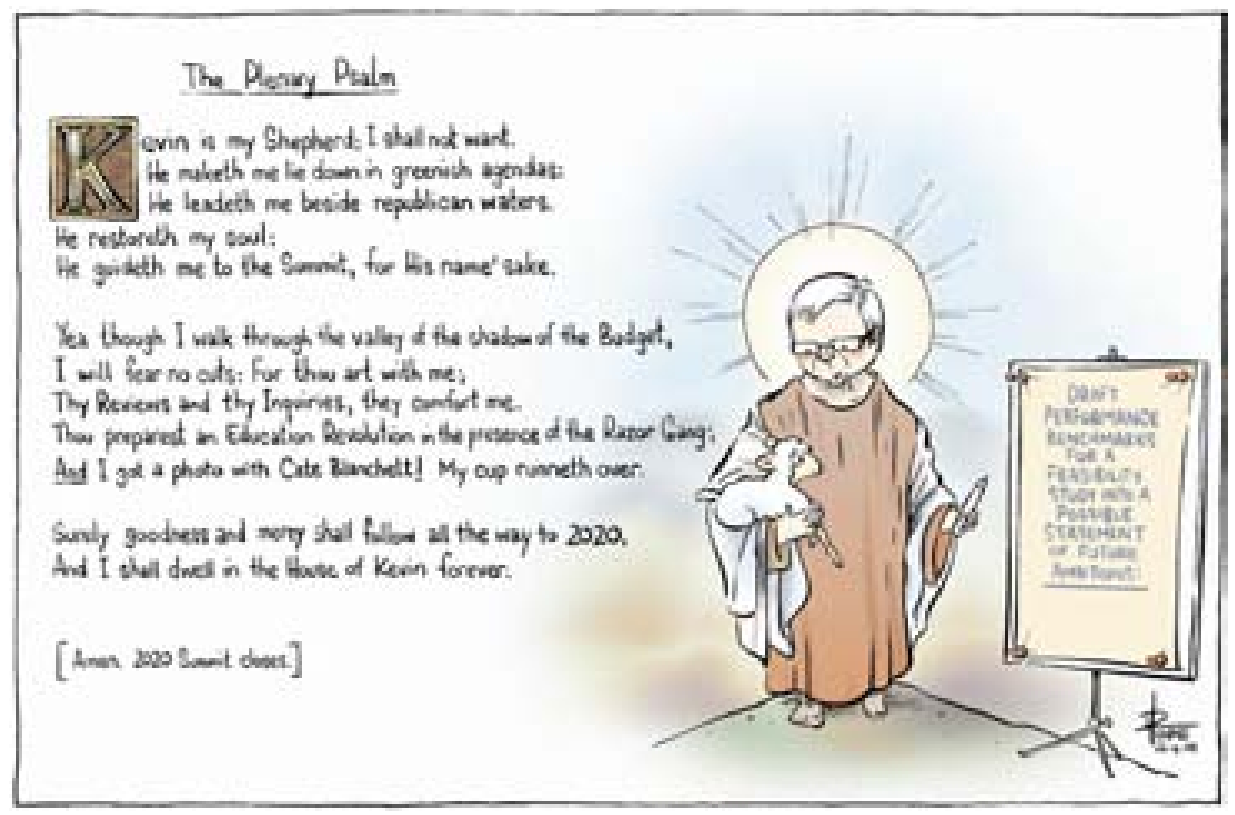

Source: David Pope, The Canberra Times, 22 April 2008

\section{What effect has the Summit had on subsequent public policy?}

Measuring influence is noticeably difficult and that is particularly the case when 900 recommendations emerged from the Summit; clearly, no government could act on all these recommendations. The government did, however, respond to all 900 recommendations in April 2009.

The government claimed that it wanted the Summit to have influence, so it is unsurprising that it subsequently claimed that it did. Of course, if there is limited evidence of the Summit having broad influence then that could be because the government did not really want it to have influence - a conclusion that would throw more doubt on the network governance model and fit much more happily with a meta-governance argument.

Of course, we have not examined all 900 of the government's responses to the Summit recommendations. Rather, we highlight two areas in which the government itself claimed that the Summit had an effect, before turning to our 
respondents' assessments (see Fawcett and Marsh 2010 for a broader treatment; and see Manwaring 2010 for a similarly sceptical assessment of the effect of the governance stream's proposals).

In the foreword to the government's response, Rudd began by highlighting two crucial areas in which the Summit had influenced policy:

The government has already acted on many of these ideas. We have commenced a major review of Australia's future tax system. We have implemented a broad program of reform of our collaboration with the states and territories, culminating in new national agreements and national partnerships in critical policy areas, including health and education, in November last year. (<http://www.australia2020.gov.au/ docs/government_response/2020_summit_response_foreword.doc > ; see also Foster 2008:6)

There is certainly no doubt that these are two areas where there were new directions. So, the government set up the Henry Tax Review in May 2008 and it reported in May 2011. In addition, there is no doubt that such a tax review was widely discussed in the 'Role of Government in the Economy' subgroup - one of five in the economy theme. The real question concerns the extent to which the idea was novel and had not previously been considered by the government. In our view - and this was shared by a number of participants in the economy stream whom we interviewed - the government was already committed to such a review.

Here, we would point to a number of factors in support of our argument. First, in the run-up to the 2007 election, Labor was widely accused of not having a tax policy, although Wayne Swan, as Shadow Treasurer, claimed during the election campaign: 'We've been talking tax reform for a long time. And if you care to go through the record, you'll see many speeches from me about tax reform, about the need to streamline the tax system' (The 7.30 Report, ABC TV, 22 October 2007). As such, tax policy was something Labor needed to address on coming to power and a review was an obvious solution for a party that could have been short of its own ideas. Second, the government was particularly active in the subgroup arguing for a review. As Foster (2008:5) emphasises: 'The group was the source of one of the key ideas - tax reform - and it was one in which both the Prime Minister and the Treasurer actively participated.' Third, the review was announced with terms of reference some three weeks after the Summit, so, it is likely that plans for a tax review were already in train. The words used when the review was announced are also interesting: 'The review follows the recent 2020 Summit, which proposed a comprehensive review of State and Federal taxes' (our italics). Note it does not say 'emerged from' or 'was suggested by', rather the more passive 'follows'. 
An even clearer picture emerges on regulatory harmonisation. This was a policy change that occurred before the Summit. Indeed, the first Council of Australian Governments (COAG) meeting after the Labor victory in 2007 established a Business Regulation and Competition Group and the COAG meeting of $26 \mathrm{March}$ 2008 developed an agenda for reform in 27 areas of business regulation. So, while the Summit clearly endorsed this development, it hardly initiated it.

In general, our respondents - all interviewed at least nine months after the Summit - were sceptical about its influence, although most acknowledged its symbolic importance. One participant in the governance stream claimed:

It was obviously a clever political exercise; you're going to get a massive list of suggestions; you're free to cherry pick any of them you want, some of which you might have done anyway and then you can hold up your head high saying 'I have listened to the people'. So, it was a bit cynical in that regard but, at the same time, I really felt that there was the sense of renewal, that it was a chance for us to move in new directions and that of the millions of ideas that had been put out there if there were just one or two ideas that had traction and that made Australia a better place or that made lives easier or better for people then that would have been worthwhile.

Some participants were also sceptical about the government's motives. So, Guest (2008:11) argues: 'Was there a net national benefit from the Summit? I doubt it. There was definitely net benefit for the government - it gave the impression that the government was listening and it was a worthwhile investment in galvanising support from opinion-makers and community leaders.'

Others, however, while acknowledging the absence of a clear effect on policy, were much less sceptical of the government's motives and saw the very process of consultation as crucial. Here, another participant in the governance stream argued:

It was clear from the beginning that the government would like to use this Summit to break down the kind of distrust that had [existed] between reform-minded public intellectuals, etc., and government. [It was a] better experience, and a positive thing, but not something that was really geared towards getting a coherent, ordered list of public policy priorities.

Overall, then, the 2020 Summit seems better viewed as an exercise to strengthen the legitimacy of government than as a genuine move towards network governance or a more participatory democracy. 


\section{Community Cabinets}

Community Cabinets were introduced by the Queensland Labor government in 1998 (see Reddel and Woolcock 2004) and involved ministers visiting various locations to receive delegations and meet with anyone who attended to discuss local issues. In that context, Reddel and Woolcock (2004:79) claim that '[t]he Community Cabinet process has extended the reach of executive government to Queensland citizens'. Certainly, to date, there have been 132 Community Cabinets in Queensland and, following a recent Community Cabinet in Roma, in which the number of delegations had almost doubled since the previous one 10 years earlier (from 67 to 129), the state's current Premier, Anna Bligh, optimistically concluded that 'far from the community tiring of those sort of events, their enthusiasm and appetite for them are increasing' (Barry 2010). As Barry also notes, however, the delegations that have attended have typically represented commercial interestsand the number of people involved has been very limited.

Subsequently, Community Cabinets have been a feature of state governance in Victoria since 2003, South Australia since 2001 and New South Wales from 2007-all, unsurprisingly, under Labor governments. All of these governments claim that Community Cabinets have extended consultation and participation, as the annual report of the NSW Department of Premier and Cabinet (2008-09) asserts: 'Community Cabinet visits give local community groups and individuals an opportunity to discuss local issues directly with the Premier, Ministers and senior leaders of the public service.'

Given this context, and Rudd's experience with Community Cabinets in Queensland, it was perhaps unsurprising that the federal Labor government introduced Community Cabinets shortly after it came to office. It claimed that 'Community Cabinet meetings are part of the Prime Minister's commitment to ensure close consultation with the Australian people on the things that concern them, whether they are national or local matters' (PM\&C 2010). Echoing this theme at the first Community Cabinet meeting in January 2008, which was attended by 600 people in Perth, Rudd asserted that ministers had come to listen, arguing that governments that did not remain in touch were not worth 'a pinch of salt' (The Age 2008). In the end, a total of 23 federal Community Cabinets were held before the 2010 election. ${ }^{8}$

Offering her impressions of that first meeting in Perth, Peatling (2008) has argued that:

8 For a list, see: <http://www.dpmc.gov.au/community_cabinet/meetings/index.cfm> 
Part parent-teacher interview, part political rally and part old-time revivalist meeting, the event boasted an hour-long general questionand-answer session where people selected to attend could ask questions.

Some people read their questions to make sure they didn't miss anything; others were clear about what to ask.

Health, home ownership, the environment and whether the Chinese government was harvesting the organs of Falun Gong supporters were all on people's minds.

The ministers sat at individual desks and conducted six 10-minute interviews. If they or their staff or public servants could not answer, they promised to send the information to the person as quickly as possible.

Peatling's first impressions were positive, but the question of what influence, if any, the Community Cabinets would have was never far away. To address this issue, we focus upon two issues widely discussed in Community Cabinet meetings to date: home ownership and disability services (for a more extended treatment, see Lewis and Marsh 2010).

\section{Home ownership}

Labor had identified the issue of housing as a key policy area in opposition and had hosted a Housing Affordability Summit on the issue in July 2007. The unanimous opinion of the 150 experts who attended was that increasing the first-home-owners' grant would simply result in higher house prices, and Labor accepted that view. So, at the 2007 election, Labor promised reform in this area, including: a dedicated housing minister; the introduction of First Home Saver Accounts to assist first-time home buyers to save for a deposit, which it subsequently implemented in February 2008; a \$600 million National Rental Affordability Scheme (NRAS), which it launched in May 2008, with the aim of boosting the supply of rental housing for poorer households through the construction of an extra 50000 homes; and a \$500 million Housing Affordability Fund, which was introduced by the government in September 2008, with the aim of lowering the cost of building new homes (Barrymore 2008; Irvine 2009b). Importantly, therefore, several of the government's most important policies on home ownership had been announced before any Community Cabinets had actually taken place and many of these policies were launched after only a handful of these meetings had been held, suggesting that their influence was limited at best.

It was also clear that both Rudd and his ministerial team often used Community Cabinet meetings as an opportunity to promote current government policy. For 
example, Rudd often used the meetings to promote aspects of the government's $\$ 10.4$ billion stimulus package, which was announced on 14 October 2008. This included provisions to help with housing construction-more specifically, a trebling of the first-home-owners' grant for newly constructed homes and a doubling of the same grant for established properties.

Specific examples of Rudd's use of Community Cabinet meetings as a means of promoting the government's stimulus package were evident at the meeting held at Geelong, Victoria, on 7 December 2008, where Rudd noted that helping first home buyers supported the housing industry and jobs (<www.dpmc.gov.au/ community_cabinet/docs/corio_comcab_transcript.pdf $>$ ). Similar sentiments to these were expressed at a subsequent meeting held on 22 April 2009 at Ballajura, Western Australia, where Rudd noted that the government had provided $\$ 62.5$ million for 4200 first-home owners in Western Australia between October 2008 and February 2009. He also used this meeting to argue that the boom in Australia's housing sector and construction industry contrasted with 'the devastation in developing economies elsewhere in the world' (<www.dpmc. gov.au/community_cabinet/meetings/ballajura.cfm $>$ ). In Elizabeth, South Australia, Rudd also used the Community Cabinet meeting, on 28 July 2009, to argue that assistance to help first-home buyers was essential to prevent retail sales from collapsing and to ensure continued economic growth (<www.dpmc. gov.au/community_cabinet/meetings/elizabeth.cfm>).

Promotion of government policies was also evident after the announcement, in February 2009, that the government would provide $\$ 6.6$ billion to build 20 000 new social housing dwellings and 802 new defence homes (Hudson 2009). Rudd noted at a Community Cabinet meeting held in Townsville, Queensland, on 8 December 2009, that the government had provided $\$ 84.9$ million to create affordable housing in north Queensland, and that such spending was helping small businesses to survive and employ apprentices (<www.dpmc. gov.au/community_cabinet/meetings/townsville.cfm $>$ ). Similarly, when asked about social housing in Tasmania at the meeting held in Hobart on 13 October 2009, Jenny Macklin, Minister for Families, Housing, Community Services and Indigenous Affairs, spoke of the $\$ 5$ billion invested in additional social housing and asserted that Tasmania 'is getting its fair share' (<www.dpmc.gov.au) community_cabinet/meetings/hobart.cfm $>$ ).

By April 2009, however, signs of a worsening housing situation were clear. Many corporations were taking advantage of the government's NRAS, which allowed investors a tax break of $\$ 8000$ per annum, per dwelling, for a decade, at a time when rental vacancy rates in Melbourne, Perth, Adelaide and Darwin were only 2 per cent (Franklin 2008). In this context, the Managing Director of SQM Research, Louis Christopher, warned that the scheme was contributing to spiralling house prices under $\$ 500$ 000, making home purchase more expensive, 
yet benefiting investors (Irvine 2009a:5). Craig James, Chief Economist at CommSec, also noted that the housing market needed many more investors and developers as a housing shortage and surge in buyer interest would result only in higher prices (Cummins 2009).

Perhaps unsurprisingly, Community Cabinet meetings did not resolve the housing crisis, which only became worse both for renters and for aspiring firsttime home buyers. To take just one example, while it was predicted that 220 000 First Home Saver Accounts would be opened in their first year, by 30 June 2009, there were just 13946 (Chancellor 2009). We would argue that, overall, the Community Cabinets were worried less with listening to the concerns of people and more about promoting the government's policy positions, although it is clear that this did change in response to both the global financial crisis and a deepening housing crisis.

\section{Disability services}

Disability services were a frequent topic at Community Cabinet meetings. In our view, however, they again had little, if any, influence on policy and served more as a forum for promoting government policy than as a genuine consultation process.

Policies to assist Australians with disabilities were announced by the Rudd government early in its term, although there was ongoing pressure for further assistance. In July 2008, the government ratified the UN Convention on the Rights of Persons with Disabilities. More specifically, in May 2008, the government announced an extra $\$ 1.9$ billion for a new commonwealth-state-territory agreement to help fund 2300 additional supported-accommodation places, a similar number of home-support packages and 10000 respite places (The Advertiser 2008). The new National Disability Agreement (2009-13) between the Commonwealth and the states and territories meant that the Australian government would contribute $\$ 5.3$ billion to state and territory-run disability services over the next five years. This included an extra \$408 million to fund services and reforms to the disability services system. The Commonwealth's contribution was to be indexed at more than 6 per cent over the life of the fiveyear agreement, compared with a previous arrangement of 1.8 per cent (Lunn 2008).

There was no doubt that these early measures were appreciated and this was reflected in the Community Cabinets. So, the mother of an autistic daughter acknowledged at the Beenleigh, Queensland, meeting, which was held on 30 June 2009, 'the tremendous things that have happened under this government in the disability employment sector and in disability advocacy. Bill Shorten is the breath of fresh air that has been missing for a long time.' 
As with our earlier example, however, the government also used Community Cabinet meetings as a forum to promote its own policies; a few specific examples should help to make this point (for a more extended treatment, see Lewis and Marsh 2010). The first example can be seen in the Community Cabinet meeting that was held in Launceston on 5 November 2008, where the government once again promoted its policy, by noting the number of disability pensioners who would benefit from its stimulus package (<www.dpmc.gov.au/community_ cabinet/meetings/launceston.cfm $>$ ).

At the Geelong meeting held on 7 December 2008 and the Townsville meeting held on 8 December 2009, Rudd again spoke of the assistance that one-off payments had given carers and people with disabilities (<www.dpmc.gov.au/ community_cabinet/meetings/corio.cfm $>$ ). Similarly, at the Ballajura meeting, the Health Minister, Nicola Roxon, emphasised Labor's efforts to establish six early childhood centres to 'support children very early in their life with autism', and argued that '[i]t's new for the Federal Government to have taken any sort of steps' (<www.dpmc.gov.au/community_cabinet/meetings/ballajura.cfm>). At the meeting at Elizabeth, Bill Shorten, Parliamentary Secretary for Disabilities and Children's Services, was asked what action the Commonwealth was taking with regards to accessibility for people with disabilities. He noted that some of the social housing being built 'will be governed under the principals of universal design', emphasised that the Howard government did nothing from 2004, and claimed 'that there is a lot more to be done but I would say that the Rudd government has put issues of access to the physical premises well and truly on the map' (<www.dpmc.gov.au/community_cabinet/meetings/elizabeth.cfm>).

What all of these examples suggest is that - as was the case in relation to housing issues - Community Cabinet meetings did not appear to make any substantive difference to existing government policy. One final example - the fate of the proposal for a national disability insurance scheme for Australia - will help to further reinforce this point.

The Disability Investment Group (DIG) was commissioned by the Rudd government in 2008 to investigate funding for the sector and called for major structural reform 'to move the care and support for people with disabilities out of the dark ages and into the 21st century', including support for a no-fault, government-funded national disability insurance scheme funded by general revenue or a Medicare-style levy (Lunn 2009b). Concerns about disability services were raised at a number of Community Cabinet meetings from April to November 2009 (<http://www.pm.gov.au/PM_Connect/Community_Cabinet/ Previous_Meetings $>$ ).

After nearly two years of debate about a national disability insurance scheme for Australia, the Treasurer, Wayne Swan (2009), indicated that the Productivity Commission 'will undertake a feasibility study into long-term care and support 
for people with disability in Australia, including investigating the feasibility for a no-fault social insurance scheme to cover people's disability and mental service needs', but only 'if it proves feasible' and 'the economy gives us the means to afford them'.

The commission is due to report in July 2011 with the result that the issue has effectively been 'put on the backburner', despite the fact that the cost of maintaining disability services has been rising at 5 per cent more than inflation (Steketee 2009), and the Australian Institute of Health and Welfare biennial report predicts that almost 2.3 million Australians will be living with a severe disability by 2030, compared with 1.5 million today (Lunn 2009a).

Based on the evidence that we have presented, it is hard to argue that Community Cabinets are genuine participatory forums. As one Labor MP argued, while most participating ministers and parliamentary secretaries were committed to these meetings because Rudd constantly emphasised the need to stay in touch at a local level, 'you really have to wonder what actually results, besides getting a hearing for the people who come' (Daley 2009). At the same time, Chalmers (2009) estimates that the cost of Community Cabinets has blown out to about $\$ 3.5$ million a year.

\section{Conclusion}

In our view, these two cases clearly indicate the limitations of the network governance argument, at least as it applies to Australia. Neither the 2020 Summit nor the federal Community Cabinet initiative seems to mark a turn towards a more participatory mode of governance, despite the Rudd government's rhetoric. Rather, we would argue that they both represent examples of meta-governance. This is because, in both cases, the Rudd government used the discourse of network governance and increased participation in the policymaking process largely as means of legitimising or promoting decisions that had already been taken. The discourse of increased participation therefore masked the continued role of hierarchy in a political system that essentially remains underpinned by a top-down conception of democracy in which network governance occurs in the 'shadow of hierarchy'.

David Marsh is a Professor in the School of Sociology, Research School of Social Science, The Australian National University.

Chris Lewis is a Research Fellow at the Centre for Policy Innovation, Research School of Social Science, The Australian National University.

Paul Fawcett is a Lecturer, Department of Government and International Relations, University of Sydney. 


\section{References}

Bang, H. 2005. 'Among everyday makers and expert citizens', in J. Newman (ed.), Remaking Governance: Peoples, politics and the public sphere, The Policy Press, Bristol, pp. 159-79.

Barry, D. 2010. 'Should community cabinets be part of democracy's furniture', 5 August, <http://nebuchadnezzarwoollyd.blogspot.com/2010/08/shouldcommunity-cabinets-be-part-of.html>

Barrymore, K. 2008. 'A budget to build on', Herald Sun, 19 May, p. 29.

Carson, L. 2008. '2020 Summit: meetings in the foothills', Australian Review of Public Affairs, April, <http://www.australianreview.net/digest/2008/04/ carson.html>

Chalmers, E. 2009. 'Cabinet proves a costly traveller', The Courier-Mail, 20 May, p. 10 .

Chancellor, J. 2009. 'Public shuns government's home saver accounts', Sydney Morning Herald, 21 November, p. 5.

Cummins, C. 2009. 'First purchase grant gives market a fillip', Sydney Morning Herald, 10 April, p. 13.

Daley, P. 2009. 'Little more than one-sided chat', Sun Herald, 24 May, p. 14.

Davis, G. 2008. 'One big conversation: the Australian 2020 Summit', Australian Journal of Public Administration, vol. 67, no. 4, pp. 379-89.

Department of the Prime Minister and Cabinet (PM\&C) 2010. Community Cabinet, Department of the Prime Minister and Cabinet, Commonwealth of Australia, Canberra, <http://www.dpmc.gov.au/community_cabinet/index. $\mathrm{cfm}>$

Fawcett, P. 2009. Government, governance and metagovernance in the British core executive, Unpublished PhD thesis, The University of Birmingham, Birmingham.

Fawcett, P. and Marsh, D. 2010. Network governance and the 2020 Summit, available from < david.marsh@anu.edu.au>

Foster, J. 2008. 'The 2020 Summit: the future of the economy', Agenda, vol. 15, no. 2 , pp. 5-7.

Franklin, M. 2008. 'Tax deal rush for low-rent housing', The Australian, 13 September. 
Guest, R. 2008. 'The 2020 Summit: population, sustainability, climate change and water', Agenda, vol. 15, no. 2, pp. 9-11.

Hudson, P. 2009. 'New stimulus worth $\$ 42$ bn', The Canberra Times, 3 February.

Irvine, J. 2009a. 'Cheap rent tax break is pushing up house prices', Sydney Morning Herald, 13 April, p. 5.

Irvine, J. 2009b. 'It's bricks and slaughter out there', Sydney Morning Herald, 22 April, p. 11.

Jessop, B. 2004. 'Multi-level governance and multi-level meta-governance', in I. Bache and M. Flinders (eds), Multi-Level Governance, Oxford University Press, Oxford, pp. 49-75.

Kickert, W. J. M., Klijn, E.-H. and Koppenjan, J. F. M. (eds) 1997. Managing Complex Networks: Strategies for the public sector, Sage, London.

Lewis, C. and Marsh, D. 2010. Network governance, metagovernance and the federal Community Cabinets in Australia, available from < david.marsh@anu. edu.au>

Lunn, S. 2008. 'New deal at COAG for the disabled', The Australian, 29 November, p. 6.

Lunn, S. 2009a. 'Disability to hit 2.3m as nation grows grey', The Australian, 18 November, p. 5.

Lunn, S. 2009b. 'Care of disabled "national disgrace", The Australian, 3 December, p. 7.

Manne, R. 2008a. 'Comment', The Monthly, May, pp. 10-13.

Manne, R. 2008b. 'What is Rudd's agenda', The Monthly, November, pp. 22-32.

Manwaring, R. 2010. As good as it gets?: the 2020 Summit and Labor's democratic renewal agenda, Paper delivered at the Australian Political Science Association Conference, Melbourne, September.

Marsh, D. (forthcoming). 'The new orthodoxy: the differentiated polity model', Public Administration.

Marsh, D. and Rhodes, R. A. W. 1992. Policy Networks in British Politics, Clarendon Press, Oxford.

Martinetto, M. 2003. 'Governing beyond the centre: a critique of the Anglogovernance school', Political Studies, vol. 51, no. 3, pp. 592-608. 
The Rudd Government

Nethercote, J. 2008. '2020 Summit snubs over-75s and Queenslanders', Crikey Online, 1 April, <http://www.crikey.com.au/2008/04/01/2020-summitsnubs-over-75s-and-queenslanders/>

Newman, J. 2005 'Introduction', in J. Newman (ed.), Remaking Governance: Peoples, politics and the public sphere, The Polity Press, Bristol, pp. 1-15.

NSW Department of Premier and Cabinet (NSW DPC) 2008-09. Annual Report 2008-2009, NSW Department of Premier and Cabinet, Sydney.

Osborne, D. E. and Gaebler, T. 1992. Reinventing Government: How the entrepreneurial spirit is transforming government, Addison-Wesley, Reading.

Peatling, S. 2008. 'Rudd in touch with tea talk', Sydney Morning Herald, 21 January.

Reddel, T. and Woolcock, G. 2004. 'From consultation to participatory governance? A critical review of citizen engagement strategies in Queensland', Australian Journal of Public Administration, vol. 63, no. 3, pp. 76-87.

Rhodes, R. A. W. 1997. Understanding Governance: Policy networks, governance, reflexivity and accountability, Open University Press, London.

Rhodes, R. A. W., Wanna, J. and Weller, P. 2009. Westminster Compared, Oxford University Press, Oxford.

Steketee, M. 2009. 'Disability insurance a real reform', The Australian, 12 September, p. 2.

Swan, W. 2009. Making every Australian count, Launch of Endeavour Foundation Endowment Challenge Fund, Brisbane, 11 December, <http:// www.treasurer.gov.au/DisplayDocs.aspx?doc=speeches/2009/034.htm\&pag $\mathrm{eID}=005 \& \min =$ wms \&Year $=\&$ DocType $>$

The Advertiser 2008. 'Editorial: \$2 bn new funding for the disabled', The Advertiser, 31 May, p. 17.

The Age, 2008. 'Community cabinets a worthwhile exercise', Editorial, The Age, 22 January 2008, <http://www.theage.com.au/news/editorial/communitycabinets-a-worthwhile-exercise/2008/01/21/1200764167390.html>

Twomey, A. 2008. 'The 2020 Summit: the future of governance', Agenda, vol. 15, no. 2, pp. 15-20. 